\title{
FIVE MORE YEARS OF THE JOINT BANK ACCOUNT MUDDLE*
}

\author{
DONALD KePNER $\dagger$
}

7 HE TWO-party bank account has been used for more than a century as a means of effectuating a form of gift with control over the subject matter and the power of revocation reserved by the donor and with the donee's njoyment of the gift postponed until the donor's death.

The reservation of dominion over the gift res by the donor runs counter to a long established rule that delivery of the chose to the donee or one acting in his behalf is an essential element of every gift. Moreover, postponement of the gift until the donor's death makes the transaction testamentary in character and conceivably subject to the statute of wills.

These defects were recognized in the early cases. In fact it was not until banks experimented with three forms of the two-party bank account that they found a formula that sufficiently disguised the transaction so as to satisfy the courts. Under one of these plans the donor opened an account in the sole name of the donee in anticipation that the latter could make withdrawals from the account as a matter of course upon the donor's death. Although the account was in the name of the donee, the deposit agreement with the bank was executed by the donor and the bank usually recognized him to be the sole owner of the funds on deposit. It is not surprising to find that in many of the cases adjudicating the rights of the parties following the depositor's death, it was held that the gift failed because of the donor's exclusive retention of control. ${ }^{1}$ As a result this form of the two-party account fell into disuse as a technique for making an inter vivos gift.

* See Professor Kepner's initial study of this problem: The Joint and Survivorship Bank Account-A Concept Without a Name, 41 Cal. L. Rev. 596 (1953).

† Professor of Law and Assistant Dean in Charge of South Jersey Division, Rutgers University School of Law.

${ }^{1}$ D. M. Read Co. v. American Bank \& Trust Co., 110 Conn. 461, 148 Atl. 130 (1930); Jones v. Ferguson, 150 Fla. 313, 7 So.2d 464 (1942); Telford v. Patton, 144 Ill. 611, 33 N.E. 1119 (1892); Peters' Adm'r v. Peters, 224 Ky. 493, 6 S.W.2d 499 (1928); Getchell v. Biddeford Savings Bank, 94 Me. 452, 47 Atl. 895 (1900); Northrop v. Hale, 73 Me. 66 (1881); Robinson v. Ring, 72 Me. 140 (1881); Broderick v. Waltham Savings Bank, 109 Mass. 149 (1872); Davis v. Lenawee County Savings Bank, 53 Mich. 163, 18 N.W. 629 (1884); Smith v. Taylor, 183 Miss. 542, 184 So. 423 (1938); Fernald v. Fernald, 80 N.H. 75, 113 Atl. 223 (1921); Marcy v. Amazeen, 61 N.H. 131 (1881); Wickford Savings Bank v. Corey, 25 R.I. 217, 55 Atl. 684 (1903); Abernathy v. Adams, 31 Tenn.App. 559, 218 S.W.2d 747 (1948); Pope v. Burlington Savings Bank, 56 Vt. 284 (1883); Howard v. Windham County Savings Bank, 40 Vt. 597 (1868); Ruffalo v. Savage, 252 Wis. 175,31 N.W.2d 175 (1948). 
The second two-party technique was borrowed from the law of trusts. The donor deposited funds in an account opened in his own name in trust for the donee, ostensibly creating a trust. A number of courts, refusing to take the transaction at face value, held that the mere act of opening the account in trust form was not in itself sufficient to create a trust. ${ }^{2}$ It was necessary to establish that there were other manifestations besides the form of the account in order to show an intention to create a trust. However, many courts held that the bank account trust was irrevocable. Since this divested the donor of control over the funds, there was no advantage in using the bank account as a means for making gratuitous transfers. Only in the few states that recognized the Tenative, ${ }^{3}$ or Totten Trust as a revocable trust did the trust bank account achieve popularity as a form for effectuating gifts.

The joint and survivorship bank account was the first device that produced the results desired by banks and their depositors, but even this technique did not meet with early success. Courts in the early cases often found that the joint account was either an abortive attempt to create a joint tenancy, an inchoate gift ineffective because of nondelivery, or an invalid testamentary disposition. ${ }^{4}$

But with banking persistence, aided by legislative assistance, the joint account has overcome these objections and has been accepted in the best judicial circles. This is evidenced by the fact that in cases arising during the past five years, the appellate courts of twenty-three states ${ }^{5}$ awarded the balance credited

2 Peters v. Goodwin, 190 Ark. 24, 76 S.W.2d 980 (1934); Denigan v. Hibernia Savings and Loan Society, 127 Cal. 137, 59 Pac. 389 (1899); Stamford Savings Bank v. Everett, 132 Conn. 92, 42 A.2d 662 (1945); Hallowell Savings Institution v. Titcomb, 96 Me. 62, 51 Atl. 249 (1901); Nutt v. Morse, 142 Mass. 1, 6 N.E. 763 (1886); Powers v. Provident Institution for Savings, 124 Mass. 377 (1878); Boyer v. Backus, 282 Mich. 593, 276 N.W. 564 (1937), cert. denied 305 U.S. 644 (1938); Frank v. Heimann, 302 Mo. 334, 258 S.W. 1000 (1924); Nicklas v. Parker, 71 N.J. Eq. 777, 71 Atl. 1135 (1907); Peoples Savings Bank v. Webb, 21 R.I. 218, 42 Atl. 874 (1899); Wilbur v. Mortgage Loan Co., 153 S.C. 14, 149 S.E. 262 (1929); Fleck v. Baldwin, 141 Tex. 340, 172 S.W.2d 975 (1943); Wood v. Wood, 87 Utah 394, 49 P.2d 416 (1935).

${ }^{3}$ Matter of Totten, 179 N.Y. 112, 71 N.E. 748 (1904); Wilder v. Howard, $188 \mathrm{Ga} .426,4$ S.E.2d 199 (1939); Hale v. Hale, 313 Ky. 344, 231 S.W.2d 2 (1950); Dyste v. Farmers \& Mechanics Savings Bank, 179 Minn. 430, 229 N.W. 865 (1930); Scanlon's Estate, 313 Pa. 424, 169 Atl. 106 (1933).

- Kepner, The Joint and Survivorship Bank Account-A Concept Without a Name, 41 Cal. L. Rev. 596, 598-603 (1953). The cases and statutes in effect in all states in 1953 are discussed.

5 Vincent v. Vincent, 224 Ark. 449, 274 S.W.2d 772 (1955); Duggan v. Hopkins, 147 Cal.App.2d 67, 304 P.2d 823 (1956); Flynn v. Hinsley, 142 Conn. 257, 113 A.2d 351 (1955); Colclazier v. Colclazier, 89 S.2d 261 (Fla. ,1956); Nash v. Martin, 90 Ga.App. 235, 82 S.E.2d 658 (1954); Gray v. Gray, 78 Idaho 439, 304 P.2d 650 (1956); Estate of Harvey v. Huffer, 125 Ind.App. 478, 126 N.E.2d 784 (1955); In re Lenders' Estate, 247 Iowa 1205, 78 N.W.2d 536 (1956); Blair v. Hass, 215 Md. 105, 137 A.2d 145 (1957); Jacques v. Jacques, 352 Mich. 127, 89 N.W.2d 451 (1958); Edwards v. Jefcoat, 230 Miss. 56, 92 So.2d 342 (1957); Dalton v. Ametican National Bank, 309 S.W.2d 571 (Mo., 1958); Slocum v. Bohuslov, 164 Neb. 156, 82 N.W.2d 39 (1957); In re Dreschler's Estate, 282 App.Div. 4, 121 N.Y.S.2d 128 (1953); Barton v. Hooker, 283 P.2d 514 (Okla., 1955); Fuller v. Fuller, 372 Pa. 239, 93 A.2d 
to a joint and survivorship bank account to the survivor upon the death of the depositor. Those recent cases which have denied the survivor a right to the balance have done so primarily because of a failure to meet the technical requirements of a joint account statute rather than upon any conceptual difficulty with the perfection of the gift.

In spite of considerable progress, recognition of the joint account as a new technique for the distribution of property has been both slow and uneven. While some states have enacted statutes which do no more than protect the bank in paying the survivor, leaving it to the courts to work out the property rights of the survivor, other states have specifically legislated upon the property rights created by joint accounts. Moreover, under whatever form of statute, the courts have moved at an uneven pace in discarding outmoded technical property concepts in ascertaining rights under a joint account, thus adding to the confusion.

The following materials trace the developments, both statutory and judicial, in the law of joint bank accounts during the past five years. As the following discussion will show, these recent developments indicate that out of the present confusion there is emerging a recognition of the joint account as a unique form of gift, and that the source of the present confusion is more a product of variation in the rate of development among the courts and legislatures than an indication of a growing divergence of views.

\section{Statutory Developarents, 1954-58}

The bank protection statute.-Legislation regulating the payment of joint bank accounts originated in New York in a widely copied statute which provided that a deposit made in the names of two or more persons, payable to either or the survivor, may be paid to either whether the co-depositor be living or not, and that the receipt or acquittance of the person paid shall be a valid release for the payment.

This type may be designated a bank protection statute, for the courts in most of the thirty-four states ${ }^{6}$ which have adopted the statute in the above form have construed it to protect the bank in making payment to the survivor without, in any manner, affecting the actual ownership of the deposit. However, in five states, ${ }^{7}$ the courts prior to 1954 , had reasoned that the legislature in

462 (1953); Hawkins v. Thackston, 224 S.C. 445, 79 S.E.2d 714 (1954); Johnson v. Johnson, 306 S.W.2d 780 (Tex.Civ.App., 1957); Miller v. Roseberry, 144 A.2d 836 (Vt., 1958); In re Webb's Estate, 49 Wash.2d 6, 297 P.2d 948 (1956); Lett v. Twentieth Street Bank, 138 W. Va. 759, 77 S.E.2d 813 (1953); Estate of Schley, 271 Wis. 74, 72 N.W.2d 767 (1955); Jansen v. Ackerman, 74 Wyo. 152, 284 P.2d 1086 (1955).

'The statutory citations are furnished in Kepner, op. cit. supra note 4, at 605 n. 10.

${ }^{7}$ O'Brien v. Bieggar, 233 Towa 1179, 11 N.W.2d 412 (1943); Dyste v. Farmers and Mechanics Bank, 179 Minn. 430, 229 N.W. 865 (1930); In re Lewis' Estate, 194 Miss. 480, 13 So.2d 20 (1943); Estate of Johnson, 116 Neb. 686, 218 N.W, 739 (1928); Estate of Staver, 218 Wis. 114, 260 N.W. 655 (1935). 
authorizing payment also intended to create property rights in the survivor, on the theory that it was unconscionable to permit the bank to pay the deposit to one who was not the owner.

During the past five years, courts $^{8}$ have interpreted their bank protection statutes to create property rights in the survivor; similarly, two legislatures ${ }^{9}$ have amended their bank protection statute to one which expressly conferred property rights in both parties in joint and survivorship accounts. A third interesting development has taken place in Virginia, where the statute was amended $^{10}$ to vest the balance in the survivor of a husband and wife joint account and to create a tenancy in common upon divorce. In view of a preamendment case $\mathrm{e}^{\mathrm{Il}}$ which refused to apply any presumptions as to the rights of survivor under the previous statute, and in view of the effect of divorce, it would appear that Virginia had amended its statute either to create a joint tenancy or at least to raise a presumption of a gift to the survivor. Which construction is correct is not certain, nor is it known whether the amendment is to be applied exclusively to husband and wife accounts.

Joint tenancy type statutes. - A second group of statutes provide that the opening of a bank account in joint and survivorship form creates a joint tenancy. In 1953, legislation of this nature had been adopted in Arkansas, ${ }^{12}$ California, ${ }^{13}$ Colorado, ${ }^{14}$ Michigan, ${ }^{15}$ Missouri, ${ }^{16}$ Nevada, ${ }^{17}$ New York, ${ }^{18}$ Washington ${ }^{19}$ and West Virginia. ${ }^{20}$ If the Virginia statute is interpreted to create a joint tenancy as to husband and wife there are ten states that have applied a statutory joint tenancy concept to bank accounts.

The only basic change in the joint tenancy statutes in the above states may be an amendment adopted in Colorado. ${ }^{21}$ The statute formerly stated that a deposit opened in the names of two or more persons and payable to either of them shall be deemed to be owned by said persons in joint tenancy with the

${ }^{8}$ Hawkins v. Thackston, 224 S.C. 445 , 79 S.E.2d 714 (1954); Barbour v. The First Citizens National Bank of Watertown, 86 N.W.2d 526 (S.D., 1957).

- Conn. Gen. Stat. (Supp., 1955) c. 289a, \$2779d; N.H. Rev. Stat. Ann. (1955) c. 384.28.

${ }^{10}$ Va. Code Ann. (Cum. Supp., 1958) §6-55.1.

II 196 Va. 844, 86 S.E.2d 141 (1955).

${ }^{12}$ Ark. Stat. (1947) $\$ 67-521$.

${ }^{13}$ Cal. Bank. Code (1949) c. 7, \$852.

14 Colo. Rev. Stat. (1953) \$14-1-3.

${ }^{15}$ Mich. Stat. Ann. (1957) c. 234, $\$ 73.303$.

${ }^{16} \mathrm{Mo.}$ Stat. Ann. (Vernon, 1949) c. $363, \S 470$.

${ }^{17}$ Nev. Rev. Stat. (1957) $\$ 663.010$.

${ }^{18}$ N.Y. Banking Law (McKinney, 1950) \$134 (commercial banks); N.Y. Banking Law (McKinney, 1950) \$171(3) (private banks).

${ }^{19}$ Wash. Rev. Code (1955) $\$ 30.20 .010$.

${ }^{20}$ W. Va. Code (1943) $\$ 3205$.

21 Colo. Rev. Stat. (Cum.Supp., 1957) §14-13-6. 
right of survivorship. The 1957 amendment added to the above clause the qualifying words, "so far as the rights and liabilities of the bank are concerned."

The question arises as to whether the amendment has the effect of converting the Colorado statute from a joint tenancy statute into a bank protection type statute. The answer should be in the negative. If the parties are joint tenants with respect to the bank, they are joint tenants for other purposes and the amendment should not change the joint tenancy concept. Moreover, Colorado recognizes that a joint tenancy with the right of survivorship may be created in personal preoprty, ${ }^{22}$ and so that there is no reason to believe that the legislature disfavors survivorship as an incident of the creation of a joint and survivorship bank account.

Banking statutes establishing property rights.-The third type of statute regulating the payment of joint accounts consists of legislation stating that the balance remaining in the account at the death of either party shall be the property of the survivor, as distinguished from statutes authorizing the bank to make payment to the survivor. The Alabama, ${ }^{23} \mathrm{Maine}^{24}$ and Vermont ${ }^{25}$ statutes are

22 Colo. Rev. Stat. (1953) \$76-1-5.

${ }^{23} \mathrm{Ala}$. Code (Cum.Supp., 1955) $\$ 128(2 a)$ : "When a deposit shall hereafter be made in any bank doing business in this state in the names of two persons payable to either of such persons, or payable to the survivor of them, the said deposit shall upon the death of either of said persons become the property of and be paid in accordance with its terms to the survivor, irrespective of whether or not the funds deposited were the property of only one of said persons, and irrespective of whether or not at the time of the making of such deposit there was any intention on the part of the person making such deposit to vest the other with a present interest therein, and irrespective of whether or not only one of said persons during their joint lives had the right to withdraw such deposit, and irrespective of whether or not there was any delivery of any bank book, account book, savings account book, or certificate of deposit by the person making such deposit to the other of such persons.

This section shall apply to certificates of deposits, as well as to savings accounts and checking accounts, and shall also apply where a deposit is made in the names of more than two persons where there is a provision for survivorship.

Nothing contained in this section shall be construed to prohibit the person making such deposit from withdrawing or collecting the same during his lifetime, nor shall the fact that such person had the right to withdraw or collect said deposit during his lifetime operate to defeat the rights herein provided for the person or persons surviving such depositor."

24 Me. Rev. Stat. (Cum.Supp., 1957) c. 59, \$19-G-V-B: All such accounts opened or such shares in loan and building associations issued on or after the 1st day of August, 1929, payable to either of 2 or more or the survivor, up to, but not exceeding an aggregate value of $\$ 3,000$, exclusive of interest and dividends, in the name of the same persons in all banks, savings banks, loan and building associations or trust companies within this state, together with the additions thereto and increment thereof, including interest and dividends, shall, in the absence of fraud or undue influence, upon the death of any of such persons, become the sole and absolute property of the survivor or survivors, even though the intention of all or any one of the parties be in whole, or in part, testamentary and though a technical joint tenancy be not in law or fact created...."

${ }^{25}$ Vt. Stat. Ann. (1958) c. 88810: "The recital of the words, "payable to either or to the survivor' or words of like effect in the order creating such account and signed by the person or persons who furnish the funds for such deposit shall be conclusive evidence, as between the payees and their legal representatives, of the creation of an absolute joint account. However, nothing herein shall prevent the proof of fraud, undue influence, or incapacity to defeat such joint interests." 
similar to the extent that each authorizes the payment of the balance to the survivor without a showing of a donative intent on the part of the party furnishing the funds, without a requirement of delivery of a passbook and independent of the facts of the original ownership of the funds deposited to the account. These statutes were enacted by the various legislatures as a result of judicial decisions denying recovery to the survivor because of non-compliance with the requirements necessary to perfect an inter vivos gift, create a trust or establish a joint tenancy. The new Connecticut ${ }^{26}$ and New Hampshire ${ }^{27}$ statutes are also of this type. Although all five statutes of this general nature have different wording, the legal effect is much the same in that they all create a new technique for transmitting property.

The 1948 New Jersey statute, ${ }^{28}$ varying somewhat from the above, provided that moneys to the credit of a joint and survivorship account may, unless otherwise provided in the depositor's contract, be paid to the survivor. The Act further provided that the legal representative of the one dying shall have no right thereto, notwithstanding that any money or any part thereof shall be the money of the one dying. Despite the provision divesting the decedent's estate of any interest in the account, the New Jersey Supreme Court held that the statute only created a rebuttable presumption of an interest by survivorship which

${ }^{26}$ Conn. Gen. Stat. (1958) c. 634, $\$ 36.3:$ "(1) When a deposit has been made in this state in any state bank and trust company, national banking association, savings bank, industrial bank or private bank, or a share account has been issued in this state by any building or savings and loan association or federal savings and loan association or credit union, in the names of two persons and in form to be paid to either or the survivor of them, such deposit or share account and any additions thereto made by either of such persons after the making or issuance thereof, together with all dividends or interest or increases credited thereon, shall be held for the exclusive use of both persons and may be paid to either during the lifetime of both or to the survivor after the death of one of them, and such payment and the receipt or acquittance of the one to whom such payment is made shall be a valid and sufficient release and discharge for all payments so made. The making of a deposit or issuance of a share account in such form shall, in the absence of fraud or undue influence, be conclusive evidence, in any action or proceeding respecting the ownership of, or the enforcement of the obligation created or represented by, such deposit or share account, of the intention of both of the named owners thereof to vest title to such deposit or share account, including all additions and increments thereto, in such survivor.

"(2) This section shall not apply to any deposit or share account referred to herein where either owner died before October 1, 1953, nor shall it apply to any action pending on said date."

${ }^{27}$ N.H. Rev. Stat. Ann. (1955) c. 384.28: "Whenever any account shall be maintained in any bank doing business in this state in the names of two persons payable to either of such persons, and payable to the survivor of them, the said account shall upon the death of either of said persons become the property of and be paid in accordance with its terms to the survivor, irrespective of whether or not the funds deposited were the property of only one of said persons, and irrespective of whether or not at the time of the making of such deposits there was any intention on the part of the person making such deposit to vest the other with a present interest therein, and irrespective of whether or not only one of said persons during their joint lives had the right to withdraw such deposit, and irrespective of whether or not there was any delivery of any bank book, account book, savings account book, certificate of deposit, or other evidence of such an account, by the person making such deposit to the other of such persons."

${ }^{28}$ N.J. Rev. Stat. Ann. (1950) Tit. 17:9A-218. 
stands until overthrown by proof..$^{29}$ In an important case involving the interpretation of the statute, judgment was rendered against the survivor on the ground that the statutory presumption of survivorship had been overcome.

In 1954, the New Jersey legislation amended the joint bank account statute by adding the following language:

When either, or both, or only 1 of the 2 persons in whose names a time or demand deposit account is maintained in any form described in this section, makes a deposit or deposits in such account, or causes a deposit or deposits to be made in such account, such person shall be conclusively presumed to intend to vest in the other a present beneficial interest in each deposit so made, and in the moneys to the credit of the account from time to time, to the end that, upon the death of the first of the 2 persons to die, all the right and title of the person so dying in and to the moneys to the credit of the account on his death, less all proper set-offs and charges, shall, at his death, vest solely and indefeasibly in the survivor. ${ }^{30}$.

The statute also preserves the rights of creditors of either of the persons in whose name the account is maintained and provides that non-compliance with the law regulating the disposition of decedent's estate does not invalidate the survivor's interest. Clearly, the legislature intended to establish a conclusive presumption of a gift. The statute has not been construed.

The Illinois statute ${ }^{31}$ is an enigma. Unlike other states, in Illinois the authorization for making payment to the survivor to a joint bank account is in the "joint rights and obligations" title of the statute and not in the banking act. The statute abolishes the rights of survivorship as an incident of joint tenancy, subject to a number of exceptions of specified transactions, including stocks and bonds, building and loan shares, and other instruments and indebtedness issued in joint form. The provision with respect to joint bank accounts provides that a deposit in any bank or deposit company made in the names of two or more persons may be paid to any one of said persons whether the other be living or not, and when an agreement permitting such payment is signed by all said persons at the time the account is opened or thereafter, the receipt or acquit-

${ }^{29}$ In re Perrone's Estate, 5 N.J. 514, 527,76 A.2d 518, 524 (1950).

${ }^{30}$ N.J. Rev. Stat. Ann. (Cum. Supp., 1958) Tit. 17:9A-218B.

3i Mll. Rev. Stat. (1957) Tit. 76, \$2: "Except as to executors and trustees, and except also where by will or other instrument in writing expressing an intention to create a joint tenancy in personal property with the'right of survivorship, the right or incident of survivorship as between joint tenants or owners of personal property is hereby abolished, and all such joint tenancies or ownerships shall, to all intents and purposes, be deemed tenancies in common; provided, that the foregoing shall not be deemed to impair the rights, privileges and immunities, as set forth in the following provisos, (a), (b), (c) and (d):

"(a) When a deposit in any bank or trust company transacting business in this State has been made or shall hereafter be made in the names of two or more persons payable to them when the account is opened or thereafter, such deposit or any part thereof or any interest or dividend thereon may be paid to any one of said persons whether the others be living or not, and when an agreement permitting such payment is signed by all said persons at the time the account is opened or thereafter the receipt or acquittance of the person so paid shall be valid and sufficient discharge from all parties to the bank for any payments so made...." 
tance of the person so paid shall be a valid and specific discharge from all parties to the bank for all payments so made.

While the language pertaining to joint bank accounts is patterned after the bank protection type statute, it is a part of the general property statute permitting survivorship, and it could be construed to authorize the establishment of a joint tenancy in a bank account. But the Illinois Supreme Court in a 1949 case $^{32}$ had held that if the deposit agreement was signed by both parties and if the agreement provided that the deposit was held "as joint tenants with the right of survivorship and not as tenants in common," the survivor took title to the proceeds in the account by reason of the contract; the court failed to decide whether or not a joint tenancy had been created. Prior cases adjudged ${ }^{33}$ by the same court had held that the rights of the survivor were established by the terms of the contract, the Illinois court having followed the Massachusetts cases on this point.

However, in In re Schneider's Estate, ${ }^{34}$ adjudged in 1955, the Illinois Supreme Court stated that the interest of the survivor in the joint account in a savings and loan account was not based on any theory of joint tenancy but depended upon whether or not the depositor made a gift. The Illinois statute did not at that time apply to savings and loan accounts. The former joint bank account cases were construed as holding that the joint deposit agreement is only evidence of a donative intent. The court appears to have repudiated the contract theory formerly followed in the joint bank account cases. It ignored the possibility that a statutory joint tenancy could be established by a joint and survivorship bank account. Admittedly, the joint bank account statute was not involved in the Schneider case. Nevertheless, the court went out of its way to limit the joint bank cases and to repudiate the contract theory. Moreover, it expressly stated that the transaction was purely a gift, which could be effective only if the depositor opened a joint account with a donative intent. The court found that the depositor had no such intent in the case under consideration and awarded the balance to the depositor's estate.

Notwithstanding that the Schneider case is dicta insofar as joint bank accounts are considered, the construction placed on the holding of prior Illinois Supreme Court cases indicate that the joint bank transaction acquires validity from a gift executed by the contract providing for payment to the donee and not the joint bank account statute. If this construction is correct, the statute protects the bank and permits parties to make agreements providing for survivorship. It does not of itself create property rights as in the case of the Alabama and New Jersey enactments. A gift does not result from the mere fact that a joint and survivorship account has been opened in a banking institution. If the policy

32 In re Wilson's Estate, 404 Iil. 207, 88 N.E.2d 662 (1949).

${ }^{33}$ Illinois Trust \& Savings Bank v. Van Vlack, 310 Il. 185, 141 N.E. 546 (1923); Reder v. Reder, 312 Ill. 209, 143 N.E. 418 (1924).

${ }^{34} 6$ Ill.2d 180, 127 N.E.2d 445 (1955). 
stated in the Schneider case is followed in subsequent joint bank account cases, it is incorrect to classify the Illinois statute regulating joint bank accounts as a special bank account statute. It is in reality a bank protection statute although codified in the property section of the Illinois code. Even if the contract theory is followed in subsequent joint bank account cases, the validity of the gift depends upon the contract and possibly the law of gifts and not the banking statute.

Case Law Deveíôpments, 1954-58: Rigets of the SuRvivor

Cases under bank protection type statutes.-Upon the death of the party furnishing the funds credited to a joint and survivorship bank account, the survivor must show that he has acquired the rights to the account under some principle of property law. In the absence of a statute vesting the property in him, the survivor may make any one of four arguments.

The most obvious basis for the survivor's claim is that he is the recipient of a gift. But to substantiate his claim of a gift either causa mortis or inter vivos, the survivor must establish that the deceased depositor intended to make a donation to the donee, that there was delivery of the subject matter and that there was an acceptance of the gift by the donee.

Since the purpose of the joint bank account gift-is to permit the donor not only to retain control of the subject matter but to dissipate it if he desires, there is no delivery in the sense that the term is used in the classical law of gifts. Delivery of the chose in the usual gift situation is effective only when the donor strips himself of dominion over the object involved. But in the joint bank account gift rarely does the donee have any real control of the account, except where the parties to the joint account are husband and wife and the joint account serves other purposes than to effectuate a gift.

Applying the historical rule that there must be delivery of the subject matter, some courts have held that a gift cannot be made of a bank deposit if the donor continues to make or reserves the right to make withdrawals. ${ }^{35}$ In view of the fact that the donor reserves the right to make withdrawals in most instances, courts in these states have held the gift invalid.

Adopting a different view, other tribunals have held that gift of an interest in a joint bank account consists of a gift of an equal right to make withdrawals during the parties' joint lives and to the right to the balance remaining in the account at the time of the donor's death. ${ }^{36}$ If the evidence discloses that the donee cannot make withdrawals during the donor's lifetime, the gift fails. The fact that the donee does not make withdrawals is unimportant. It is the right to use the account, not the fact of usage that is significant.

${ }^{35}$ Crowell v. Milligan, 157 Neb. 127, 59 N.W.2d 346 (1953); Balfour's Estate v. Seitz, 392 Pa. 300, 140 A.2d 441 (1958).

${ }^{36}$ Cournoyer v. Monadnock Sav. Bank, 98 N.H. 385, 102 A.2d 910 (1953); Ottjes v. Littlejohn, 285 S.W.2d 243 (Tex.Civ.App., 1955); Barbour v. First Citizens Nat. Bank, 86 N.W.2d 526 (S.D., 1957). 
Another view recognizes the impossibility of delivery in the traditional form ${ }^{37}$ and. requires merely an indication of a donative intent by the depositor when opening the account coupled with the execution of requisite bank forms. Closely akin is the holding that the execution of the contract is tantamount to delivery. ${ }^{38}$ Upon a showing that there was an intention to make a gift coupled with the granting of authority to the donee to make immediate withdrawals, courts find that an inter vivos gift has been effectuated, notwithstanding that the donor may still make withdrawals.

A second property theory, now discarded in all states, awarded the account balance to the survivor as beneficiary of a trust. This is not the trust account set up as such. The word trust appears nowhere in the deposit agreement. The courts which applied the trust theory to ordinary joint and survivorship accounts reasoned that since the donor intended to make a gift, but reserved control over the res, he intended to act as a trustee of the funds for the benefit of the donee. This theory cannot be justified and it is not surprising that it has been generally rejected. Clearly a person opening an ordinary joint and survivorship bank account does not intend to assume the obligations of a trustee, nor for that matter, does he intend to give away anything but the balance remaining in the account upon his death.

A third theory for sustaining the joint bank account gift is based on the property concept of joint tenancy. The common law joint tenancy could be created in the common law only where there was a unity of time, title, interest and possession. By reason of the fact that the party furnishing the funds for the joint account has control over the account, and is not generally accountable to the donee for withdrawals, there is no real unity of interest or possession. Moreover, in the ordinary situation the donor does not intend to create a true joint tenancy which would constitute the donee a half owner when the account is opened. A true common law joint tenancy cannot be created in the usual joint account ${ }^{39}$ where the donor has the power to use all the funds in the account, leaving nothing at his death.

The common law joint tenancy has also been a favorite object of legislation. At one time in some states this form of co-ownership in all types of property was abolished..$^{40}$ In other jurisdictions, the jus accrescendi as an incident of a joint tenancy is not recognized so that there can be no survivorship.11 Also, a considerable number of legislatures have enacted a third form of legislation stating that property jointly owned is to be presumed to be owned as tenants in com-

${ }^{37}$ Spark v. Canny, 88 So.2d 307 (Fla., 1956).

${ }^{38}$ Harrington v. Emmerman, 186 F.2d 757 (App. D.C., 1950); Stewart v. Barksdale, 216 Miss. 760, 63 So.2d 108 (1953).

${ }^{39}$ Appeal of Garland, $126 \mathrm{Me}$. 84, 136 Atl. 459 (1927); Marble v. Jackson, 245 Mass. 504, 139 N.E. 442 (1923); In re Lower's Estate, 48 S.D. 173, 203 N.W. 312 (1925).

${ }^{40}$ Allen v. Almy, 87 Conn. 517, 89 Atl. 205 (1913); Miles v. Fisher, 10 Ohio 1 (1840).

${ }^{11}$ Ariz. Rev. Code (1956) \$14-204; N.C. Gen. Stat. (1950) \$41-2. 
mon. ${ }^{42}$ However, if the statute merely states the presumption is against a joint tenancy, the deposit agreement authorizing payment of the balance to the survivor rebuts the presumption, and the courts find a joint tenancy can be created in joint accounts.

Where common law joint tenancies have been abolished, it is still possible in some jurisdictions to constitute the parties to the joint bank account tenants in common with the balance to pass to the survivor under the law of future interests. ${ }^{43}$ Moreover, in a number of states joint tenancy as a means of co-ownership of property is becoming popular and is receiving legislative approval. Joint ownership of government bonds, stock certificates and other forms of evidence of indebtedness is widely used. In the states permitting a joint tenancy in personal property, it is not surprising to find that joint and survivorship bank accounts are construed to create joint tenancies with a right of survivorship, notwithstanding that the banking statutes are silent on this point.

Some of the jurisdictions that have not recognized joint tenancies in personal property or that have held that it is impossible to make a gift of an interest in a joint bank account without relinquishing control over the account, nevertheless hold that the contract between the depositor and the bank which authorizes payment to the survivor is to be enforced. ${ }^{44}$ The survivor is declared to be entitled to the deposit without reference to any established rules of property. The courts ignore completely such matters as whether or not the depositor had a donative intent when opening the account or whether he intended to create a present joint interest in favor of other parties whose names appeared on the account.

The contract between the bank and the depositor only instructs the bank to make payment to designated parties. It does not determine ownership of the depositor's interest in any manner. No one would argue that if a depositor opened an account with stolen funds, the real owner would not be permitted to recover the amount traced and deposited notwithstanding that the bank is obligated to pay to the depositor and not the owner of the money credited to the account. While the deposit agreement may be evidence of a donative intent or while it may create a joint interest, it does not independently of the law of gifts of joint tenancy transfer any interest in the account. As the law pertaining to joint bank accounts matures, it is predicted that the contract theory will fall into disrepute.

The development of the case law is thus influenced not only by the banking statutes but by the efforts of courts to find a theory to justify the joint bank account gift. Due to the fact that the joint account transaction does not fit any

${ }^{42}$ Ark. Stat. (1947) §50-411; 25 Del. Rev. Code (1953) §701; Iowa Code (1946) §557.15; Vt. Rev. Stat. (1947) §2632.

4s Blodgett v. Union \& New Haven Trust Co., 111 Conn. 165, 149 Atl. 790 (1930); Berberick v. Courtade, 137 Ohio St. 297, 28 N.E.2d 636 (1940).

14 Malone v. Sullivan, 136 Kan. 193, 14 P.2d 647 (1952); Chippendale v. North Adams Savings Bank, 222 Mass. 499, 111 N.E. 371 (1916); Cleveland Trust Co. v. Scobie, 114 Ohio St. 241, 151 N.E. 373 (1926); Holt v. Bayles, 85 Utah 364, 39 P.2d 715 (1934). 
of the common property concepts, courts go from theory to theory seeking one that describes the gift.

The cases decided between 1954-58 in jurisdictions having bank protection statutes reflects the search for an acceptable theory, the evolution of new concepts and the development of standards for the creation of the new joint bank account gift. It is because the various jurisdictions are in different stages of development in their understanding of the joint account transaction that the present law is in such a muddle. The following cases will indicate the extent of the confusion and the progress of development toward a recognition of the joint account gift as a new concept.

During the period under review, the appellate courts of four states ${ }^{45}$ held that the contract of deposit authorizing the bank to pay to either of the named parties or the survivor established a joint tenancy with the right of survivorship. The courts did not appear concerned with the technical requirements of the common law for establishing joint tenancies in personal property, although the cases were decided under the law applicable to personal property in general, and not under the statutes authorizing the bank to pay the survivor in joint accounts.

In two of these states the cases were of particular significance in that they were the first decisions applying the joint tenancy theory in these states. The cases were similar only in the sense that the term joint tenancy was used. Georgia, one of the states involved, has abolished the common law joint tenancy. Nevertheless, the Georgia court, noting that such a tenancy could be created by contract in a savings and loan account, held that the joint deposit agreement effectively established survivorship. ${ }^{46}$ As used in this context the term joint tenancy means nothing more than rights similar to a common law joint tenancy may be created in a tenancy in common by contract. The words "joint tenancy" are only symbolic of survivorship and the other incidents of the common law joint tenancy are not involved. On the other hand, the Idaho court, ${ }^{47}$ also in a case of first impression, found that the joint account agreement created a statutory joint tenancy with a right of survivorship under general property law.

Although they concede that a joint tenancy with the right of survivorship may be created in a bank account by reason of general personal property law, there is a line of recent cases holding that the opening of a bank account in joint and survivorship form is not of itself sufficient to create the right of survovorship to the non-contributing party, unless the account is opened by the depositor with the intention to make a gift. Some of the recent cases in the states which apply the joint tenancy theory to the joint bank account recognize this

${ }^{45}$ Nash v. Martin, 90 Ga.App. 235, 82 S.E.2d 658 (1954); Gray v. Gray, 78 Idaho 438, 304 P.2d 650 (1956); Barton v. Hooker, 283 P.2d 514 (Okla., 1955); Fuller v. Fuller, 3.72 Pa. 239, 93 A.2d 462 (1953).

${ }^{16}$ Nash v. Martin, 90 Ga.App. 235, 82 S.E.2d 658 (1954).

${ }^{47}$ Gray v. Gray, 78 Idaho 438, 304 P.2d 650 (1956). 
principle. ${ }^{48}$ If the depositor opens an account or changes his individual account to a joint and survivorship account to make it possible for someone else to make withdrawals solely for the benefit of the depositor, and not with a donative intent, there is no gift, and the death of the depositor does not divest the latter's estate of his interest in the account. 49

The depositor may fail to express his intention when opening the account. Although there are recent holdings that a presumption arises in favor of the survivor when the deposit agreement recites that all funds in the account belong to the parties as joint tenants with the right of survivorship, ${ }^{50}$ there is also authority holding that the presumption is against a gift, and that the donee must show that the account was opened for this purpose. ${ }^{51}$

Despite the fact that the donor must intend to make a gift when opening the account in joint tenancy form, he is not required to relinquish all dominion over the account in accordance with the rule pertaining to inter vivos gifts. The donative intent to transfer a present interest plus the creation of the account is sufficient. But if the evidence discloses that the donee was in some manner prohibited from making withdrawals, the gift fails. ${ }^{52}$ The gift of an interest in the joint bank account is not the balance, but the right to make withdrawals. If the donee cannot make withdrawals until the donor's death, the gift is testamentary and is invalid.

It is submitted that this requirement is an anachornism. The fact that the donee cannot make withdrawals may be evidence of the donor's intention, but it should not be conclusive on the question of whether or not a gift was made. The joint bank account gift is actually not intended to be a donation of an unrestricted right to make withdrawals, but is a present gift of the balance of the account, with the donee's enjoyment postponed until the donor's death. It is intended to be a form of a testmentary disposition of property in that the gift is not perfected until the donor's death. The gift should not be invalidated because the donee cannot make withdrawals.

In some jurisdictions, the rights of the survivor in recent cases are still being determined in accordance with the classical law of gifts. ${ }^{53}$ The burden of proof

${ }^{48}$ Murray v. Gadsden, 197 F.2d 194 (App. D.C. 1952); Spark v. Canny, 88 S.2d 307 (Fla., 1956); Balfour's Estate v. Seitz, 392 Pa. 300, 140 A.2d 441 (1958); Barbour v. The First Citizens Nat. Bank, 86 N.W.2d 526 (S.D., 1957).

49 Thompson v. Thompson, 244 F.2d 374 (App. D.C., 1957) Barbour v. The First Citizens Nat. Bank, 86 N.W.2d 526 (S.D., 1957).

${ }^{50}$ Spark v. Canny, 88 So.2d 307 (Fla., 1956); In re Fell's Estate, 369 Pa. 597, 87 A.2d 310 (1952); In re Webb's Estate, 49 Wash.2d 6, 297 P.2d 948 (1956). The latter case arose under a bank protection type statute, now repealed.

${ }^{51}$ Imirie v. Imirie, 246 F.2d 652 (App. D.C., 1957); Murray v. Gadsden, 197 F.2d 194 (App. D.C., 1952).

52 Balfour v. Seitz, 392 Pa. 300, 140 A.2d 441 (1958); First Security Bank of Utah v. Burgi, 122 Utah 445, 251 P.2d 297 (1952).

53 Flynn v. Hinsley, 142 Conn. 257, 113 A.2d 351 (1955) (former statute); In re Schneider's Estate, 6 IIl.2d 180, 127 N.E.2d 445 (1955); Wyatt v. Moran, 81 R.I. 399, 103 A.2d 801 (1954). 
may be on the survivor to show the gift. Frequently he cannot show the donor's intention and most of the time he cannot establish delivery. Because there had been no delivery gifts were invalidated in Connecticut and New Hampshire cases, a fact which no doubt influenced the legislatures to enact statutes eliminating the elements of intention and delivery in the joint bank account transaction.

The Courts have been taking another look at the contract theory during the period under review. Both the District of Columbia ${ }^{54}$ and the Illinois Courts ${ }^{55}$ rejected the contract theory, stating that the contract of deposit does not transfer an interest in the account to the donee in the absence of an intent to make a gift. In both cases the evidence established that the account was opened for the depositor's convenience.

On the other hand, the South Carolina Supreme Court applied the contract theory in a case of first impression in that jurisdiction..$^{56}$ The court seemed to be impressed with the reasoning of the courts that have adopted this theory. It must be noted, however, that the Court construed the contract of deposit in light of the joint bank account statute which authorizes the bank to make payment to the survivor of accounts opened in joint and survivorship form. While the court did not expressly so state, it is implicit in the court's decision that the bank account statute is evidence of a legislative intent to enforce the joint bank account agreement.

It clearly appears that even under the joint tenancy, and the contract theory, the donor's intention is the most important element in the transaction. The cases indicate that the contract is the instrument for executing a form of gift with the donee's full enjoyment postponed until the donor's death. The main difference between the various theories is the matter of presumptions and burden of proof.

In cases arising in states which follow any of the accepted theories for sustaining gifts created by joint accounts, more and more language appears relating to the competency of the depositor, the presence or absence of undue influence, and the determination of whether or not a confidential relationship exists between the survivor and the depositor. The depositor must be competent, ${ }^{67}$ and the account must not have been established as a result of undue influence or fraud $\mathrm{d}^{58}$ exercised by the survivor on the donor. If a confidential relationship exists, the burden is on the survivor, the donee, to show that the donor understood the nature of the transaction and intended to make a gift. ${ }^{59}$ Unquestion-

54 Murray v. Gadsden, 197 F.2d 194 (App. D.C., 1952).

B5 In re Schneider's Estate, 6 Ill.2d 180, 127 N.E.2d 445 (1955).

${ }^{56}$ Hawkins v. Thackston, 224 S.C. 445, 79 S.E.2d 714 (1954).

${ }^{67}$ In re Wann's Estate, 176 Pa.Super. 498, 108 A.2d 820 (1954).

${ }^{58}$ Harvey v. Huffer, 125 Ind.App. 478, 126 N.E.2d 784 (1955); Fuller v. Fuller, $372 \mathrm{~Pa}$. 239, 93 A.2d 462 (1953).

${ }^{52}$ Fuller v. Fuller, 372 Pa. 239, 93 A.2d 462 (1953); In re Wann's Estate, 176 Pa.Super. 498, 108 A.2d 820 (1954). 
ably, the transaction is gratuitous regardless of the theory used to uphold it.

A new development is the use of a joint deposit agreement which, in addition to the usual language, recites that the provision in the agreement with respect to survivorship is binding on heirs, devisees, legatees, next to kin, assignees and personal representatives of the parties. In Pennsylvania, ${ }^{60}$ Texas $^{61}$ and Wyoming $^{62}$ the courts held this language to be significant, and, in each instance, awarded the balance in the account to the survivor. The Wyoming case was decided without reference to any of the traditional theories for upholding the survivorship provision.

Maryland is the only state that currently applies the trust theory in sustaining the rights of the survivor. But in Maryland, the courts have approved a form of deposit agreement which expressly provides that the account is in trust for both named parties as joint owners subject to the order of either, the balance at the death of one to belong to the other. ${ }^{63}$ This is to be distinguished from the early cases sustaining the joint account gift on the ground that an implied trust had been established.

Aside from the form of the account, the Maryland cases raise the same general problems as other forms of the joint and survivorship account. Recent cases have held that building and loan accounts cannot be distinguished from joint bank accounts ${ }^{64}$ and that the establishment of the joint account in trust form raises a rebuttable presumption of a valid trust and gift..$^{65}$ If a confidential relationship exists, the burden of proof as to the fairness and reasonablenss of the transaction shifts to the surviving donee. ${ }^{66}$ The one distinguishing feature in the Maryland case law is the holding that while the declaration of trust in the contract of deposit is evidence of the depositor's intention, it is not the exclusive method of creating a trust. Oral evidence may be admitted to show an intention to create a joint bank account trust, although the deposit does not expressly so state. ${ }^{67}$

The distinction between common and civil law of gifts is reflected in litigation arising in Louisiana ${ }^{68}$ in which the survivor unsuccessfully attempted to recover the balance remaining in a joint and survivorship account. The court observed

${ }^{60}$ In re Furjanick's Estate, 375 Pa. 484, 100 A.2d 85 (1953).

${ }^{61}$ Adams v. Jones, 258 S.W.2d 401 (Tex.Civ.App., 1953); Johnson v. Johnson, 306 S.W.2d 780 (Tex.Civ.App., 1957).

62 In re Jansen's Estate, 74 Wyo. 152, 284 P.2d 1086 (1955).

${ }^{63}$ Milholland v. Wahlen, 89 Md. 212, 43 Atl. 43 (1899); Dougherty v. Dougherty, 175 Md. 441, 2 A.2d 433 (1938); Ragan v. Kelly, 180 Md. 324, 24 A.2d 289 (1942).

64 Bierau v. Bohemian Building \& Loan Association, 205 Md. 456, 109 A.2d 120 (1954).

${ }^{65}$ Blair v. Haas, 215 Md. 105, 137 A.2d 145 (1957); Shook v. Shook, 213 Md. 603, 132 A.2d 460 (1957).

${ }_{66}^{6}$ Tribull v. Tribull, 208 Md. 490, 119 A.2d 399 (1956).

${ }^{67}$ Bierau v. Bohemian Building \& Loan Association, 205 Md. 456, 109 A.2d 120 (1954).

${ }^{68}$ Bordelon v. Brown, 84 So.2d 867 (La.App., 1956). 
that the statute requires inter vivos gifts of incorporeal things to be executed before a notary public in the presence of two witnesses, subject to exceptions not pertinent to the instant case. Since the joint account transaction did not comply with the statute relating to gifts, the survivor acquired no interest in the account. Louisiana has a bank protection type statute which has been construed to protect the banks in making payment, and not to confer rights upon the survivor. ${ }^{69}$

Attention is directed to the fact that in Iowa, ${ }^{70}$ Minnesota, ${ }^{71}$ Mississippi, ${ }^{72}$ Nebraska ${ }^{73}$ and Wisconsin, ${ }^{74}$ the bank protection type statute has been construed to confer property rights in the survivor in addition to protecting the bank in making payment. The nature of the interest is not clear in some states, although in other states the interest is that of a statutory joint tenancy. ${ }^{75}$

The trend in these states is to hold that opening the account in joint and survivorship form creates a rebuttable presumption of an intent to create a present interest in the donee. ${ }^{76}$ The presumption may be rebutted by showing that the joint account was opened solely for the convenience of the depositor, or that he retained exclusive control despite the form of the account. ${ }^{77}$ If a present interest is not transferred, the account is treated as a void testamentary disposition..$^{78}$ If the surviving donee occupies a position of trust and confidence with the decedent, the burden shifts to the donee to show that the donor intended to make the gift and was aware of the nature of the transaction. ${ }^{79}$ Practically, the only difference between the cases in these states and the cases in states that construe the statute only to protect the bank, is the recognition by the former states of a presumption of gift to the survivor.

Cases under the joint tenancy bank account statutes.-As has been observed previously the statutes in a number of states provide that an account opened in joint and survivorship form shall create a joint tenancy with the right of survivorship. But in order to come within the provisions of the statute, it is

${ }^{69}$ Northcott v. Livingood, 10 So.2d 401 (La.App., 1942).

${ }^{70}$ O'Brien v. Bieggar, 233 Iowa 1179, 11 N.W.2d 412 (1943).

7 Dyste v. Farmers and Mechanics Sav. Bank, 179 Minn. 430, 229 N.W. 865 (1930).

72 In re Lewis' Estate, 194 Miss. 480, 13 So.2d 20 (1943).

${ }^{73}$ Slocum v. Bohuslov, 164 Neb. 156, 82 N.W.2d 39 (1957); Estate of Johnson, 116 Neb. 686, 218 N.W. 739 (1928).

74 Estate of Staver, 218 Wis. 114, 260 N.W. 655 (1935).

${ }^{75}$ In re Ware's Estate, 218 Miss. 694, 67 So.2d 704 (1953); Slocum v. Bohuslov, 164 Neb. 156, 82 N.W.2d 39 (1957); In re Schley's Estate, 271 Wis. 74, 72 N.W.2d 767 (1955).

${ }^{76}$ In re Lenders' Estate, 247 Iowa 1205, 78 N.W.2d 536 (1956); Edwards v. Jefcoat, 92 So.2d 342 (Miss., 1957); Slocum v. Bohuslov, 164 Neb. 156, 82 N.W.2d 39 (1957); In re Pfeifer's Estate, 1 Wis.2d 609, 85 N.W.2d 370 (1957).

${ }^{77}$ Nelson v. Rasmussen, 164 Neb. 274, 82 N.W.2d 418 (1957).

${ }^{78}$ Crowell v. Mulligan, 157 Neb. 127, 59 N.W.2d 346 (1953).

${ }^{79}$ Nelson v. Rasmussen, 164 Neb. 274, 82 N.W.2d 418 (1957). 
well settled that the account must be opened in the prescribed statutory form.

Deviations from the approved form are of two general types. In one the donor-depositor attempts in some manner to limit the payment of the account to the donee until the former's death. In the other type the deposit agreement does not provide for survivorship.

An attempt to restrict the donee's use of the account is illustrated in a recent Arkansas case ${ }^{80}$ where the depositor instructed the bank to notate on the signa ture card that it was payable after the death of "S. S. Powell." Inasmuch as the statute makes no provision for any such reservation in a joint and survivorship account, the joint account was not in statutory form and joint tenancy had not been created. The other type of deviation is illustrated by a recent Michigan case $^{81}$ in which the donor opened the account in the names of himself and another without making any provision for survivorship. Again we have a situation in which the account was not created in accordance with the statute, and the statutory joint tenancy was not created.

The most important development in the entire case law of joint accounts resulted from a case decided by the Court of Appeals of New York. There is no doubt but that New York has been the leader in the establishment of a body of joint bank account law. New York was the first state to provide for statutory recognition of a joint tenancy in a bank account. It was the courts of this state that held that although the New York statute established a conclusive presumption of an intention to vest title in the survivor in an account opened in statutory form, the presumption was rebuttable during the lifetime of both the named parties to the account.82

More recently the New York Court of Appeals introduced an entirely new concept in In re Creekmore's Estate. ${ }^{83}$ This litigation had its origin in an unusual set of facts, unusual because the donor acted under advice of counsel. Mrs. Creekmore instructed her daughter to have the former's attorney prepare a power of attorney to enable the daughter to make withdrawals from three bank accounts in Mrs. Creekmore's name. One bank, upon the authority of the power of attorney, permitted the daughter to make withdrawals. Two other banks, refusing to permit the agent to draw checks, suggested to Mrs. Creekmore's lawyer that a joint account be established for the mother and daughter. This was done. Mrs. Creekmore conferred with her attorney in private before executing the forms setting up the joint and survivorship account. Following the depositor's death, the surviving daughter who was also executrix of her mother's will, did not charge herself with the proceeds of the, two joint accounts. The surrogate's ruling, charging the executrix with the balance in the two accounts, was reversed by the Appellate Division of the Supreme Court.

${ }^{80}$ Powell v. Powell, 222 Ark. 918, 263 S.W.2d 708 (1954).

${ }^{81}$ Betker v. Ide, 335 Mich. 291, 55 N.W.2d 835 (1952).

82 Marrow v. Moskowitz, 255 N.Y. 219, 174 N.E. 460 (1931); In re Porieanda's Estate, 256 N.Y. 423, 176 N.E. 826 (1931).

831 N.Y.2d 284, 135 N.E.2d 193 (1956). 
In a four to three decision, the New York Court of Appeals reversed the Appellate Division, reasoning that although the statute created a conclusive presumption of an intent to create a joint tenancy with the right of survivorship in respect to an account opened in a savings bank, evidence may be admitted to show whether or not the depositor was legally competent at the time of the joint account or at the time an individual account was changed to a joint account. This goes no further than former cases. However, the court further held that the burden of proof is on the survivor to prove the competency of the depositor at the time of the establishment of the joint and survivorship bank account, in the same manner that the burden of proof is on the proponent of establishing the competency of the testator and the genuineness of a will. The survivor failed to show that the depositor was legally competent to change her individual account to a joint and survivorship account.

The case opens a whole new area of law in joint accounts. By requiring the donee to establish the competency of the donor-depositor, the court has furnished the last necessary step to convert the joint and survivorship account into a form of testamentary disposition with substantially all the incidents of the will. The only major difference between the will and the joint account is in the formalities connected with their execution. The New York court in the Creekmore case has probably gone further than the courts of other states in this matter.

However, courts in other states having joint tenancy type statutes have also raised the question of whether the depositor was legally competent when the account was opened, ${ }^{84}$ whether he knew the consequences of opening an account in statutory form ${ }^{85}$ and whether there was undue influence exercised by the survivor. ${ }^{86}$ These cases all carry overtones of the law of wills.

The opening of an account in statutory form creates a rebuttable presumption of a joint tenancy, ${ }^{87}$ placing the burden of proof on the depositor's estate to show that he did not intend to create an interest in the survivor by reason of opening the joint account. In Missouri, the parol evidence rule precludes oral evidence to show the depositor only intended to open the account for his own convenience, particularly if both parties to the joint account sign the deposit agreement stating that the amount credited to the account shall belong to the survivor upon the death of either. ${ }^{88}$ There are cases holding the contrary view. ${ }^{89}$

${ }^{8 *}$ Vincent v. Vincent, 224 Ark. 449, 274 S.W.2d 772 (1955); Potter v. Chamberlin, 344 Mich. 399, 73 N.W.2d 844 (1955); Bannasch v. Bartholomew, 350 Mich. 546 ,87 N.W.2d 78 (1957).

${ }_{85}^{85}$ Tesch v. Miller, 227 Ark. 74, 296 S.W.2d 392 (1956); Vincent v. Vincent, 224 Ark. 449, 274 S.W.2d 772 (1955).

${ }^{86}$ Kilfoy v. Fritz, 125 Cal.App.2d 291, 270 P.2d 579 (1954).

${ }^{87}$ Jacques v. Jacques, 352 Mich. 127, 89 N.W.2d 451 (1958); Potter v. Chamberlin, 344 Mich. 399, 73 N.W.2d 844 (1955); Clay County State Bank v. Simrall, 259 S.W.2d 422 (Mo.App., 1953).

${ }^{88}$ Connor v. Temm, 270 S.W.2d 541 (Mo.App., 1954).

${ }^{89}$ In re Creekmore's Estate, 1 N.Y.2d 284, 135 N.E.2d 193 (1956). 
If the donee does not sign the agreement, parol evidence is admissible in any case to show the depositor's intention. ${ }^{90}$

Clearly the element of gift is present. Unless evidence is inadmissible either under the parol evidence rule, or the statute, to show the depositor opened the account for his own convenience, and not for the purpose of making a gift, the courts hold even under the joint tenancy type bank statute it may be established that a joint tenancy has not been created and the survivor acquires no interest by reason of the depositor's death..$^{91}$ Nevertheless, the joint tenancy statute creates presumptions in favor of the donee, arising from the creation of the account in statutory form.

No doubt the joint tenancy type bank statutes create property rights. In a recent case, the Michigan Supreme Court reiterated its former position, stating that the joint bank account created a statutory method of transferring property. ${ }^{92}$ The West Virginia Supreme Court expressing the matter somewhat differently stated that the joint bank account statute restored the element of survivorship to deposits made in a bank, although the element of survivorship in joint tenancy as to property in general had been abolished. ${ }^{93}$

Courts have consistently held that the rights of the parties in joint accounts are determined by the statute in effect at the time the account is opened. This is an important factor in some of the California cases, which involve accounts opened during a period of time when the California statute provided that an opening of a joint account in statutory form in the absence of fraud or undue influence created a conclusive presumption of an intent to establish survivorship..$^{94}$ Although the presumpiton is now rebuttable, cases are currently being adjudicated involving the former conclusive presumption.

Cases in states with special statutes. -During the period from 1954-1958, there were three important cases adjudicated under special enactments regulating joint accounts. In a New Jersey case ${ }^{95}$ where the court held that under the 1948 statute, the creation of the account in joint form established only a rebuttable presumption of the creation of a joint interest, notwithstanding the language in the statute stating in effect that the heirs and personal representative of the decreased depositor are divested of all interest in the joint account. The 1954 amendment previously discussed ${ }^{96}$ should change the result of this case, since

${ }_{90}$ Dalton v. American National Bank, 309 S.W.2d 571 (Mo., 1958).

${ }^{11}$ Powell v. Powell, 222 Ark. 918, 263 S.E.2d 708 (1954); Clay County State Bank v. Simrall, 259 S.W.2d 422 (Mo.App., 1954); In re Creekmore's Estate, 1 N.Y.2d 284, 135 N.E.2d 193 (1956).

${ }^{92}$ Jacques v. Jacques, 352 Mich. 127,89 N.W.2d 451 (1958).

${ }^{93}$ Lett v. Twentieth Street Bank, 138 W. Va. 759, 77 S.E.2d 813 (1953).

${ }^{94}$ Kilfoy v. Fritz, 125 Cal.App.2d 291, 270 P.2d 279 (1954); Medeiros v. Cotta, 134 Cal.App.2d 452, 286 P.2d 546 (1955).

${ }^{95}$ Gagliano v. Maggio, 32 N.J. Super. 219, 108 A.2d 185 (1954).

${ }^{96}$ See note 30 supra. 
the presumption is now conclusive under the statute, provided the statute is construed as written.

The most unusual case was one adjudged in New Hampshire. ${ }^{97}$ For the first time in all the reported cases relating to joint bank accounts, the survivor disclaimed the balance remaining in the account, notwithstanding that under the terms of the statute, he was entitled to the funds on deposit at the donor's death. His right to disclaim was upheld in a proceeding brought by the New Hampshire State Tax Department to assess a tax against the survivor on the balance in the account. The court noted that the gift was wholly inoperative unless accepted by the donee and that the survivor did not receive property taxable under the statute.

The third significant case in this group is Miller v. Roseberry ${ }^{98}$ adjudged by the Supreme Court of Vermont in 1958. The administrator of the depositor's estate sued the survivor to set aside a gift created by a joint bank account, alleging that the survivor was guilty of fraud and undue influence with respect to the joint account. Construing the Vermont joint bank account statute, the court declared that in the absence of fraud or undue influence the recital of the words "payable to either or the survivor" shall be conclusive evidence of the creation of a joint account.

The plaintiff's allegation of fraud and undue influence were found to be too general resulting in the trial court sustaining a general demurrer to the plaintiff's complaint. Affirming the trial court, the reviewing court also found that the complaint failed to establish the existence of a fiduciary relationship between the depositor and the survivor. The rules applicable to gifts made to a fiduciary were not, therefore, involved. The entire opinion indicates that the Vermont court has an interest in interpreting the statute to achieve the legislative policy of enforcing joint bank account gifts.

In both Connecticut and New Hampshire, cases involving the right of survivorship were decided under common law principles regulating gifts, upon a finding that the recent amendments to the joint bank account statute conferring property rights in the survivor did not apply to the account in question. ${ }^{99}$ Although in the New Hampshire cases the survivor was unable to sustain the burden of proving a valid gift, he was more fortunate in Connecticut for the donor had the foresight to deliver the passbook to the donee at the time he expressed an intention to make a gift. Under the statutes in Connecticut and New Hampshire now in effect, the question of the intention of the donor is no longer material, the property vesting in the survivor upon the death of either of the joint depositors. Unless there is fraud or undue influence, the making of the

${ }^{97}$ Bradley v. State, 100 N.H. 232, 123 A.2d 148 (1956).

98144 A.2d 836 (Vt., 1958).

99 Flynn v. Hinsley, 142 Conn. 257, 113 A.2d 351 (1955); Chretien v. Duhaime, 100 N.H. 254, 124 A.2d 208 (1956); Cournoyer v. Monadnock Savings Bank, 98 N.H. 385, 102 A.2d 910 (1953). 
deposit in statutory form is all that is required to effectuate the gift. Former cases in both states will have no application to joint accounts subject to the new statutes.

\section{Case Law Developanents, 1954-58: Inter Vivos Disputes}

Rights of the depositors during their joint lives.-Reference has been made repeatedly to the fact that the joint and survivorship bank account is a new technique for effectuating a gift by which the donor retains the power of revocation and under which the donee's enjoyment of the gift is postponed until the donor's death.

This is clearly demonstrated in the cases involving disputes over the funds credited to the account during the depositors' joint lives. For, notwithstanding the fact that the courts pay lip service to the proposition that a gift of a joint interest is created by the opening of the account in joint and survivorship form, in all states the subsequent declaration of the person opening the account is admissible to show that the bank account was opened in joint form to enable funds to be withdrawn for the convenience of the owner of the money deposited and not for the purpose of making a gift. ${ }^{100}$

The law of gifts requires that the donor relinquish dominion. In practice, the depositor of the funds credited to the joint account does not surrender control during his lifetime. The gift is as conditional as a will and is, in fact, perfected only by the death of the donor. The inter vivos disputes clearly establish that the transaction is gratuitous, that it is inchoate until the death of the donor, and that it depends upon the intention of the depositor and not upon the form of the account for its validity.

The cases during the past five years involving inter vivos disputes between the parties were of one of the following four varieties: (1) While both parties are still alive one of the named parties to the joint account sues the co-depositor to recover funds withdrawn by the latter. ${ }^{101}$ (2) A suit is brought to compel the restoration of a co-depositor's name to the account after the depositor changes the joint account to an individual account. ${ }^{102}$ The party who has furnished the funds and who is responsible for opening the joint account authorizes the change in the joint account to one in his individual name. (3) The co-depositors are husband and wife who are engaged in a marital dispute and who have been initiating proceedings leading to a division of property. ${ }^{103}$

${ }^{100}$ Medeiros v. Cotta, 134 Cal.App.2d 452, 286 P.2d 546 (1955); In re Estate of Lyons, 90 So.2d 39 (Fla., 1956); Loeb v. Dry Dock Savings Bank, 4 App.Div.2d 190, 164 N.Y.S.2d 408 (1957), aft'd 4 N.Y.2d 811, 149 N.E.2d 894 (1958); Jones v. Neu, 150 N.E.2d 858 (Ohio App., 1958); Zander v. Holly, 1 Wis.2d 300, 84 N.W.2d 87 (1957).

101 Landman v. Landman, 136 A.2d 392 (Mun.Ct.App. D.C. 1957); Stranger v. Epler, 382 Pa. 411, 115 A.2d 197 (1955).

${ }^{102}$ Zander v. Holly, 1 Wis.2d 300, 84 N.W.2d 87 (1957).

${ }^{103}$ Jones v. Hamilton, 211 Md. 371, 127 A.2d 519 (1956); Campagna v. Campagna, 150 N.E.2d 699 (Mass., 1958); Loeb v. Dry Dock Savings Bank, 4 App.Div.2d 190, 164 N.Y.S.2d 408 (1957), aff'd 4 N.Y.2d 810, 149 N.E.2d 894 (1958). 
(4) Following the death of the depositor, the survivor seeks to recover moneys withdrawn by the decedent during his lifetime. ${ }^{104}$ However, the manner in which the dispute arises has little, if any, bearing upon the rights of the parties to the account while both are alive.

The cases continue to hold that the party furnishing the funds for the account during his lifetime may show that he had no intention to make a gift, notwithstanding the form of the account. This is true in states which have statutes providing that the opening of the account in joint and survivorship form creates a joint tenancy ${ }^{105}$ and is also true in states that have a bank protection type statute. ${ }^{106}$ Not only may a party opening the account withdraw all the funds, but he may also terminate the interest to the co-depositor by merely instructing the bank to strike the latter's name from the account $t^{107}$ or to substitute another name. ${ }^{108}$ These acts are treated as tantamount to a withdrawal.

If joint tenancies are in fact established by the opening of an account in joint form, so that the survivor is entitled to the proceeds, it should follow that the donee has an interest in the account during his lifetime. ${ }^{109}$ But it does not work this way. If the depositor claims during his lifetime that he did not intend to create the joint tenancy, notwithstanding the form of the account, the courts have found that no such tenancy was created and that the party opening the account and furnishing the funds prevailed over the non-contributing party.

An even more complicated problem is presented by those courts which bold that a tenancy by the entirety may be created by the opening of a joint account in the name of husband and wife. Clearly, tenants by the entirety have rights other than that of survivorship. This was asserted in a case decided in Florida during the past five years resulting from an attempt on the part of the surviving spouse to recover funds withdrawn during his lifetime by the decreased spouse claiming that the tenancy was not destroyed by the withdrawal. ${ }^{110}$ The Supreme Court of Florida found that there was no intention to create a tenancy by the entirety, although in one instance the court noted that the parties had intended to create a joint account with the balance to be paid to the survivor. Whether or not a 104 Medeiros v. Cotta, 134 Cal.App.2d 452, 286 P.2d 546 (1955); Winters v. Parks, 91 So.2d 649 (Fla., 1956); In re Whiteside's Estate, 159 Neb. 362, 67 N.W.2d 141 (1954).

${ }^{105}$ Medeiros v. Cotta, 134 Cal.App.2d 452, 286 P.2d 546 (1955); Loeb v. Dry Dock Savings Bank, 4 App.Div.2d 190, 164 N.Y.S.2d 408 (1957), aff'd 4 N.Y.2d 811, 149 N.E.2d 894 (1958).

${ }^{106}$ Landman v. Landman, 136 A.2d 392 (Mun.Ct.App. D.C., 1957); In re Estate of Lyons, 90 So.2d 649 (Fla., 1956); Jones v. Neu, 150 N.E.2d 858 (Ohio App., 1957); Bell v. Bakerstown Savings \& Loan Association, 385 Pa. 158, 122 A.2d 411 (1956); Zander v. Holly, 1 Wis.2d 300, 84 N.W.2d 87 (1957).

${ }^{107}$ Zander v. Holly, 1 Wis.2d 300, 84 N.W.2d 87 (1957).

${ }^{108}$ Medeiros v. Cotta, 134 Cal.App.2d 452, 286 P.2d 546 (1955).

${ }^{109}$ Scanlon v. Scanlon, 6 Ill.2d 244, 127 N.E.2d 435 (1955); In re Dreschler's Estate, 282 App.Div. 4, 121 N.Y.S.2d 128 (1953); Stanger v. Epler, 382 Pa. 411, 115 A.2d 197 (1955).

${ }^{110}$ In re Estate of Lyons, 90 So.2d 39 (Fla., 1956).

111 Winters v. Parks, 91 So.2d 649 (Fla., 1956). 
tenancy by the entirety is created depends entirely on the matter of intention. The form of the account furnishes no clue. In the inter vivos cases, the courts usually find the parties did not intend to create a tenancy by the entirety.

The cases remain in disagreement as to whether or not the bank may pay one party to a joint savings account where the rules of the bank require that the passbook be presented, and the person withdrawing the funds did not have possession of the passbook. It has been recently held that the bank may not waive the requirement that the passbook be presented and the bank, consequently, may be held liable for payment made without such presentation. ${ }^{112} \mathrm{~A}$ contrary view has been expressed based on the theory that since the joint obligee has the power to release the debt owed by the bank, he has the minor power to waive the requirement of the production of the passbook. ${ }^{113}$ Since past cases have been in disagreement on this point, ${ }^{114}$ the two cases merely added another authority to each point of view.

Although there are cases where the co-party has recovered money withdrawn by the depositor who opens the account, ${ }^{115}$ either the depositor opened the account with funds which belonged to the claimant or the deposit was made from funds previously held in joint tenancy or a tenancy by the entirety. A deposit of funds in the joint account will not divest the real owner of his interest in such funds. :

Claims of creditors.-Not infrequently, a creditor of one of the parties to a oint and survivorship bank account seeks to subject all or part of the account to his claim. In addition to the question of the actual ownership of the account, these controversies raise the procedural questions of the burden of proof of ownership, and the issue of whether the account is subject to levy or garnishment pending this determination.

Cases adjudicated prior to 1954 established that the parties to a bank account, ostensibly held in joint tenancy, may show in fact that a joint tenancy was not created, and that only the party furnishing the funds for the account has a present interest subject to levy. ${ }^{116}$ At best, the creditor of the apparent donee could claim that the form of the joint account establishes a rebuttable presumption that his debtor owns one-half interest. ${ }^{117}$ However, the presumption of even a half interest may be overcome. ${ }^{18}$ In the states which did not

112 Badders v. Peoples Trust Co., 140 N.E.2d 235 (Ind., 1957).

${ }^{113}$ Forbes v. First Camden National Bank \& Trust Co., 25 N.J.Supro. 17, 95 A.2d 416 (1953).

114 Id., at 21 and 418.

216 Landman v. Landman, 136 A.2d 392 (Mun.Ct.App. D.C., 1957); Chovit v. Kulik, 171 N.Y.S.2d 301 (Sup.Ct., 1958).

${ }^{116}$ Spear v. Farwell, 5 Cal.App.2d 111, 42 P.2d 391 (1935); Staton v. Vernon, 209 Iowa 1123, 229 N.W. 763 (1930); Schnur v. Dunker, 38 S.W.2d 282 (Mo.App., 1931); Norcross v. 1016 Fifth Ave. Co., 123 N.J. Eq. 94, 196 Atl. 446 (1938).

117 Dover Trust Co. v. Brooks, 111 N.J. Eq. 40, 160 Atl. 890 (1932); American Oil Co. v. Falconer, 136 Pa.Super. 598, 8 A.2d 418 (1939).

${ }^{118}$ Schnur v. Dunker, 38 S.W.2d 282 (Mo.App., 1931). 
recognize joint tenancies in joint accounts, the depositor furnishing the funds may show that no present interest passed to the co-party, and that the latter had no interest during the depositor's lifetime subject to levy. ${ }^{119}$

The trend of the recent cases is to hold that the form of the account creates a presumption of a gift to the non-contributing party, that the account is subject to garnishment, and that the burden is on the co-party to show that the debtor does not have a present interest.

Three important recent cases have supported the above propositions. The Appellate Division of the New York Supreme Court held that the opening of the account in joint form created a rebuttable presumption that the depositors own the account as joint tenants. ${ }^{120}$ Moreover, the balance in the account is subject to garnishment by the creditor of either, subject to release to the extent that the co-depositor establishes his interest in the account.

The California District Court of Appeals' decision in Tinsley v. Bauer ${ }^{121}$ appears to be consistent with the policy stated by the New York court. Following a levy on a joint account by the creditor of the wife, the husband filed a claim to the account. The appellate court held for the creditor, stating that the husband must show the property levied on is his separate property or community property not derived from the earnings of his wife. The husband was unable to sustain this burden. His further claim that only one-half of the joint account was subject to claims of his wife's creditors was also denied, the court finding that the presumption that money in a "joint tenancy account of husband and wife is joint tenancy property" is rebuttable. The evidence established that the wife provided the money deposited.

The same result was reached in an Illinois case $\mathrm{e}^{122}$ where the joint depositor intervened in a garnishment action instituted against his co-depositor. In this instance the court reasoned that if the garnishee answers that a judgment debtor has an interest in a joint account, a prima facie case is established that the account belongs to the judgment debtor. The burden is on the co-depositor to establish his interest.

However, a contrary result was reached in a recent New Jersey case. ${ }^{123}$ It was held that the debtor's interests in the joint account be shown to be non-existent, although the account was ostensibly held in joint tenancy, and also that the burden of proof on the issue of the debtor's interest is on the creditor.

The New Jersey case is clearly wrong. An account opened in statutory form establishes a rebuttable presumption of gift. The parties to the account, not the creditor, should have the burden of proving any interest claimed in

119 Kranjcec v. Belinak, 114 Mont. 26, 132 P.2d 150 (1943); Union Properties, Inc. v. Cleveland Trust Co., 152 Ohio St. 430, 89 N.E.2d 638 (1949).

${ }^{120}$ Denton v. Grumbach, 2 App.Div.2d 420, 157 N.Y.S.2d 91 (1956).

121125 Cal.App.2d 724, 271 P.2d 116 (1954).

${ }_{122}$ Leaf v. McGowan, 13 Ill.App.2d 58, 141 N.E.2d 67 (1957).

123 Esposito v. Palovick, 29 N.J. Super. 3, 101 A.2d 568 (1953). 
excess, or less than the one-half interest arising from the presumption of a joint interest. Bank accounts in joint names give the appearance of assets to creditors of either of the depositors. The creditor should have the benefit of presumption of a one-half ownership in each depositor with the burden of proof being placed on the claimant, if the realities of ownership are different from the apparent joint interest of the parties to the joint account. It should make no difference whether the statute creates a joint tenancy in a joint and survivorship account as it does in California and New York, or whether the joint deposit statute protects the bank and the gift is established under a common law principle. The fact of opening a joint and survivorship account in itself may result in the creation of an interest of some sort in the donee. If so, it should be subject to his debts.

Suppose the creditor of the party furnishing the funds does not seek to subject the joint account to his claim until after the death of his debtor. In a 1956 decision, the Supreme Court of Nebraska ${ }^{124}$ held that in the absence of a showing that the account was opened to hinder, delay or defraud creditors, the survivor will prevail against the creditor of the decedent, even though the other assets were not sufficient to satisfy the creditors' claims. The result seems just. The death of the donor perfects the gift, and, in the absence of fraud, cuts off all subsequent claims against the account by defendant's creditors.

Claims of guardians.-Although the statutes authorizing the payment of the balance in a joint account to the survivor may also establish property rights in the survivor, such statutes are silent as to the rights of either party when the co-party is declared mentally incompetent and a guardian is appointed to administer his property.

In Wisconsin and Alabama litigation has resulted from the act of the guardian in withdrawing the entire balance in a joint account, which had been opened by the ward prior to his incompetency and with his own funds. Although conceding that the ward could make withdrawals, if competent, the donee claimed that the guardian had no such right.

Both the Supreme Courts of Wisconsin ${ }^{125}$ and Alabama ${ }^{126}$ in these cases held that a joint account created a joint tenancy, and that, although the ward could have withdrawn the balance in the absence of incompetency, this was a personal privilege which did not pass to the guardian. The guardian could not destroy the right of survivorship in the donee by closing the joint account. The right of the guardian to use funds in the account for the care of the ward, if necessary, was conceded, although such withdrawals are subject to court approval. However, the character of the account can not be changed by making a withdrawal of all the funds for the purpose of opening a guardianship account.

There is much to be said for the analysis adopted in these cases. The joint

124 DeForge v. Patrick, 162 Neb. 568, 76 N.W.2d 733 (1956).

${ }^{125}$ Boehmer v. Boehmer, 264 Wis. 15, 58 N.W.2d 411 (1953).

${ }^{226}$ Howard v. Imes, 265 Ala. 298, 90 So.2d 818 (1956). 
account transaction is a gratuitous one, with some of the incidents of a gift of a present interest of some sort, and part of the incidents of a will, including the power of revocation. Since the donor can withdraw for his own use, his guardian should be permitted to withdraw such amounts as are needed for the care of the ward. The opening of an account is at least a gift of the balance unexpended upon the depositor's death, and the donee's interest should be protected to the extent that funds not in the joint account should be used by the guardian before dipping into the joint account. On the one hand it is unconscionable to permit the ward to suffer because of lack of funds if there is money in the joint account. On the other hand, the donor's intent to make a gift, absent special circumstances, should be observed by the guardian. The ward's will is not revoked by incompetency, and similarly a joint account should not be so revoked. If the incompetent did not furnish any of the proceeds, the co-party furnishing funds for the joint account should be permitted to close the account. His right of revocation should not be changed by incompetency of the donee.

A guardian may recover funds withdrawn from a joint account opened by the ward, where the joint account was opened and withdrawals made as a result of undue influence exercised by the donee. ${ }^{127}$ If the donee occupies a dominant position with respect to the depositor, a presumption of undue influence arises, and the burden is on the donee to rebut the presumption. Also, there exists a duty on the part of the guardian to preserve the estate of the ward. This duty would include the recovery of money wrongfully taken from the ward's account. If the account was opened during the period of incompetency, the usual presumption of intent to make a gift does not apply. ${ }^{128}$

\section{The Future of the JoINT AND SURvivorship Bank Account}

Present state of the law.-Judicial statements with respect to the status of the joint bank gift range from continued attempts to identify the joint account by traditional concepts to recognition of the account as a new and useful technique for transferring property which need not fit any historical molds.

The first view finds expression in an 1955 opinion by the Virginia Supreme Court of Appeals in which it was stated:

The question whether the funds in a joint savings bank account with a survivorship clause belong to the survivor on the death of one of the parties has been the subject of much legislation and litigation in all of the States. We are told that every State, except Kentucky, has enacted statutes regulating the payment of joint accounts opened in the name of two or more persons. . . For more than half a century, the courts of this country have struggled to discover whether a joint deposit bank account with an extended right of survivorship, sometimes called a "poor man's will," is a gift, a trust, a contract, a joint tenancy, or a testamentary disposition. ${ }^{129}$

${ }^{127}$ Childs v. Shepard, 213 Ga. 381, 99 S.E.2d 129 (1957); Toomey v. Moore, 325 P.2d 805 (Ore., 1958).

${ }^{128}$ Schreiber v. Lovewell, 314 Ill.App. 201, 40 N.E.2d 803 (1942).

129 King v. Merryman, 196 Va. 844, 849, 86 S.E.2d 141, 143 (1955). 
A contrary view was recently stated by a Texas court who after noting that the courts of other states had applied the law of gifts, trusts and contracts to determine the validity of the agreement, declared: "We do not indulge in a prolonged discussion of the academic. The agreement having validity must be enforced irrespective of the reasons sustaining it."130

The state of the law of joint bank accounts is not as hopeless as it may seem, notwithstanding appearances to the contrary. The fact is that the law regulating joint accounts in banks develops in three stages. In the initial state, the appellate courts of a jurisdiction either refuse to accept the joint account transaction as an instrumentality for executing a gift, or if the technique is recognized, the survivor's interest is determined on the basis of some common law concept. Typical examples are cases of first impression decided by the courts of Idaho and South Carolina ${ }^{131}$ during the past five years in which the court found either that a joint tenancy had been created with a right of survivorship, or that the survivor was entitled to the balance because the contract of deposit so provided. In both controversies, the court found it necessary to select a theory to justify the result.

After a number of cases have been decided by an appellate court in a given state, it becomes less exacting in the technical requirements necessary for enforcing the agreement between the bank and the depositors which authorized payment to the survivor. When language appears in the cases suggesting that the contract is a substitute for delivery under the law of gifts, or that a joint tenancy has been created by the account agreement without any discussion of the four unities usually associated with joint tenancies, the second stage of development has been reached. This is demonstrated in Stewart v. Barksdale involving a savings and loan joint account adjudged by the Mississippi Supreme Court in 1953. In awarding the balance remaining in the account at the time of the donor's death, the court suggested that if a "gift be an element in the situation, there was an effectual consummation of the gift by way of delivery of the written instrument to the bank as the performance agent of the donee, as well as the donor."132 Mississippi courts have upheld joint bank account gifts for a number of years.

The third stage is identified by judicial recognition that the joint bank account transaction is a new concept. This is accompanied by decisions which work out the requisites necessary to insure the enforcement of the right of survivorship, the creation of presumptions resulting from the act of opening a statutory joint account, the consequences of undue influence and fraud, and

${ }^{130}$ Adams v. Jones, 258 S.W.2d 401, 403 (Tex. Civ. App., 1953).

131 Gray v. Gray, 78 Idaho 439, 304 P.2d 650 (1956); Hawkins v. Thackston, 224 S.C. 445, 79 S.E.2d 714 (1954).

${ }_{132}$ Stewart v. Barksdale, 216 Miss. 760, 766, 63 S.E.2d 108, 109 (1953). 
the rights of creditors of the depositors. Michigan, ${ }^{133}$ New York, ${ }^{134}$ and Pennsylvania ${ }^{135}$ have adjudicated cases on all these points.

At the present time the courts of different states are deciding joint bank account cases at different levels of development. While the South Carolina Supreme Court ${ }^{136}$ was deciding for the first time that a survivor was entitled to the proceeds of a joint bank account, the Supreme Court of Illinois ${ }^{137}$ was shifting from the contract to the gift theory in ascertaining whether or not the gift was perfected, and the New York Court of Appeals ${ }^{138}$ was adding to its body of joint bank account law the principle that the donee-survivor has the burden of proving the competency of the donor-depositor. The difference lies in the rate of development, not the pattern.

Notwithstanding that the law is at different stages of development, there appears to be uniformity in finding that the interest of the survivor arises by reason of a gift from the decedent. The intention to make a gratuitous transfer is essential, regardless of the common law theory used to describe the transaction. Since the donor may revoke the account during his lifetime, or may show, in resistance to the claims of creditors of the co-depositor, that a gift was not intended, the joint and survivorship bank account is in practice a testamentary disposition of property. The donee's rights are not fixed until the death of the donor.

The future of the joint account gift.-Not all joint bank accounts are opened for the purpose of making a gift. Sometimes a joint account is opened by a depositor for the sole purpose of enabling someone else to make withdrawals for the benefit or convenience of the depositor. He has no donative intention. The other purpose, the more common one, for opening the joint account is to make a gift of the balance in the account, effective upon the death of the depositor. The joint account may also serve other purposes during the donor's lifetime, although the depositor also intends that the funds unexpended at his death pass to the co-party.

If banks would permit joint deposits without survivorship, much litigation could be avoided. The presumption should be against a donative intention on the part of the depositor when a joint account is opened without survivorship, and the burden of proof should be on the co-depositor to show the account was

${ }^{133}$ Potter v. Chamberlin, 344 Mich. 399, 73 N.W.2d 844 (1955); Murphy v. Michigan Trust Co., 221 Mich. 243, 190 N.W. 698 (1922).

${ }^{134}$ In re Creekmore's Estate, 1 N.Y.2d 284, 135 N.E.2d 193 (1956); Matter of Fenelon's Estate, 262 N.Y. 308, 186 N.E. 794 (1933); Moskowitz v. Marrow, 251 N.Y. 380, 167 N.E. 506 (1929).

${ }^{135}$ In re Furjanick's Estate, 375 Pa. 484, 100 A.2d 85 (1953); In re Fell's Estate, $369 \mathrm{~Pa}$. 597,87 A.2d 310 (1952).

${ }^{138}$ Hawkins v. Thackston, 224 S.C. 445 , 79 S.E.2d 714 (1954).

${ }^{137}$ In re Schneider's Estate, 6 III.2d 180, 127 N.E.2d 445 (1955).

${ }^{133}$ In re Creekmore's Estate, 1 N.Y.2d 284,135 N.E.2d 193 (1956). 
not created for the depositor's convenience. This is in contrast to the opening of a joint and survivorship account which should, and does in some states create a rebuttable presumption of an intent to make a gift of the balance to the survivor of the proceeds remaining in the account at the death of the party opening the account and furnishing the funds. The burden of proof should be on the decedent's estate to show the depositor did not intend to create the right of survivorship, and not the survivor. Legislation should be enacted which distinguishes between the convenience and the gift joint account.

There can be no doubt that the joint and survivorship bank account is in our law to stay. This is indicated by the fact that all states except Kentucky have statutes regulating the payment of joint bank accounts and that the legislatures of an increasing number of jurisdictions are amending these statutes so as to create property rights by opening an account in joint form. Moreover, many states are applying the concept of survivorship to joint savings and loan accounts in addition to joint bank accounts, indicating there is no legislative policy against creating rights of survivorship. Clearly the joint bank account has also received general judicial acceptance, although some courts are more exacting in the formalities required for establishing the right of survivorship than are others.

Courts should at this point recognize that the joint and survivorship bank account (gift) is testamentary in character, with both parties having limited rights. The explanation for sustaining the gift, as stated by a Texas court, is now "academic in nature." Attention should be directed to resolving the rights of creditors of both the donor and donee, the rights of guardians, to developing a body of procedural law and to establishing the formalities necessary to provide for survivorship.

Until this is done the joint account muddle will be with us. But with the enactment of more adequate legislation and with judicial recognition of the fact that the joint and survivorship bank account gift is a new technique for transferring property, and with increasing attention being given to the various interests created by the joint account, by legal scholars, ${ }^{139}$ the confusion will ultimately disappear. There is no doubt but that a new body of law is slowly emerging which will fully outline the rights of all claiming an interest of any description in the joint and survivorship account.

${ }^{139}$ Jones, The Use of Joint Bank Accounts as a Substitute for Testamentary Disposition of Property, 17 U. of Pitt. L. Rev. 42 (1955); Sayre, A Review of Iowa Contract Law, 38 Iowa L. Rev. 506, 517 (1953); Bank Accounts; Transfer of Property at Death, 23 U. of Chi. L. Rev. 289 (1956); Disposition of Bank Accounts, Poor Men's Will, 53 Col. L. Rev. 103 (1953); The Theories of Joint Bank Accounts, $42 \mathrm{Ky}$. L. J. 125 (1953); The Joint and Survivorship Bank Account, Ill. Law Forum 655 (1957). There are other materials dealing with local law or with specific joint bank account problems, such as the rights of the creditors. The above citations represent good discussions of the theory of joint bank accounts. 